\title{
Observations on stammering after localized cerebral injury
}

\author{
R. K. JONES \\ From the Department of Neurological Surgery, Lankenau Hospital, Philadelphia, Pennsylvania, U.S.A.
}

Despite the advances made in the understanding of speech mechanisms in the past few decades (Nielsen, 1946; Penfield and Roberts, 1959), stammering remains as much of an enigma as ever and continues to be relegated to the province of non-organic disease for want of information clearly explaining its aetiology. It had been suggested in the past (Travis, 1931) that stammering might have a neurophysiological basis, perhaps in the form of bilateral cerebral representation for speech. The high percentage of left handedness and ambidexterity among stammerers (Bryngelson, 1932) lent further support to a theory suggesting an imperfect degree of cerebral dominance and/or bilateral cerebral activity as factors concerned in the mechanism of stammering, but the lack of techniques to test these hypotheses brought an end to this line of thought.

It is quite clear that the majority of people use one cerebral hemisphere, nearly always the left, for speech (Penfield and Roberts, 1959). However, there have been some recent suggestions that certain individuals organize their speech mechanisms in both cerebral hemispheres (Branch, Milner, and Rasmussen, 1964). Such individuals are usually left handed or ambidextrous and often show evidence of 'mixed' cerebral dominance in other sensory modalities, i.e., eyedness, earedness, and footedness.

Some of this recent information relating to cerebral speech dominance centres around Wada's intracarotid amytal test (Wada and Rasmussen, 1960) which is used to forecast neurological deficits following surgery for temporal lobe epilepsy, speech being the major parameter under consideration. It was felt that this technique would offer a method of further evaluating stammerers should the opportunity present itself.

The present study is concerned with four patients who had intracranial lesions in the region of the presumed 'speech areas' and incidentally stammered. Their stammering was unquestionably severe, had been present since childhood, and was obviously unrelated to their intracranial pathology.

These patients were studied pre- and post- operatively with particular reference to their speect $\frac{\bar{b}}{\bar{c}}$

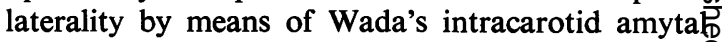
test as well as by all other measurable manifestations of cerebral dominance such as eyedness, earedness, and footedness. Wada's intracarotid amytal test waso used almost exactly as originally suggested by him in 1960 and is described below.

An 18 gauge needle was inserted into the commoris carotid artery as for a carotid arteriogram. The right and left sides were injected on different days in orderi to have maximum alertness and cooperation frow the patient: no premedication was given as a ruse Using a $5 \mathrm{ml}$. syringe, $10 \%$ sodium amytal in do of 150 to $200 \mathrm{mg}$. was injected moderately quickifye (1 to $2 \mathrm{sec}$.). The injection was made with the patie counting, with forearms up in the air and the fingerst either moving constantly or gripping an examine gs hand. The knees were drawn up so that the feet wereresting on the table close to the buttocks. As injection was completed, the contralateral arm andd leg would slump to the table and become flaccid. The ipsilateral arm and leg would remain up in thes air and voluntary movements could be carried outo on this side on command as soon as the initial fewö seconds of confusion were over. The patient would $\mathbb{Q}$ usually hesitate or stop counting near the end of the injection, but if the non-dominant hemisphere had 3 been injected, would resume on request in five to 20 seconds and then would name objects accuratelyo while the contralateral hemiplegia was still complete

When it was the dominant hemisphere that had been injected the patient was unable to continuecounting while the contralateral hemiplegia was 3 . complete. On command the patient would carry out voluntary movements with the ipsilateral extremities, 3 as soon as the initial brief period of confusion hado passed, demonstrating that he was cooperating and that lack of speech was not caused by disturbances of consciousness or cooperation. As tone and power began to return in the contralateral arm and leg, the $N$ patient began to respond with 'yes' and 'no' and then N was able to count. There was usually a period of one N to three minutes during which typically dysphasic 
responses such as perseveration and inability to name objects would occur, then normal speech returned.

Handedness was determined by Goodglasses's criterion which states that most skilled acts must be done by the hand contralateral to the dominant hemisphere (eating, cutting, handling tools). Writing itself does not indicate the side of cerebral dominance, nor does it constitute ambidexterity when done with one hand when all other skilled actions are done with the other.

Earedness was determined with bi-aural phonographic recordings.

Stammering is used to describe only the speech of those persons who have an almost constantly recurring 'block' of major magnitude as they speak, even though this varies with different circumstances and with different sets of key words. Primary school teachers and speech therapists were used as judges in this group of cases to determine whether the application of the term 'stammerer' was valid.

\section{CASE REPORTS}

CASE 1 A.H. (Lankenau Hospital case no. B 68482), a boy, aged 13 years, was left handed, left footed, right eared, and right eyed.

He was the second of three children born by normal delivery. Early development was normal but he had greater difficulty than his school mates in fastening buttons and shoe laces and was felt to be generally clumsy. His father and older brother were left handed; his sister and mother were right handed. Initially speech was 'normal' but it was noticed by his parents that he began to stammer at about the fifth year of life. This speech impediment continued, unabated, until the time of surgery. His stammering was considered severe by his grammar school teachers, friends, and parents.

Neurologically this patient was well until six months before admission to hospital when he began to complain of headache and had occasional episodes of morning vomiting. Eventually a left frontal brain tumour was considered and the patient was admitted to hospital where diagnostic procedures were carried out.

Preliminary angiography revealed the presence of a

TABLE I

PRE-OPERATIVE RESULTS OF THE INTRACAROTID AMYTAL TEST IN FOUR PATIENTS

\begin{tabular}{|c|c|c|c|c|c|c|c|c|c|c|c|}
\hline \multirow{2}{*}{$\begin{array}{l}\text { Case } \\
\text { No. }\end{array}$} & \multirow{2}{*}{$\begin{array}{l}\text { Dose } 10 \% \\
\text { NaAmytal } \\
\text { (mg.) }\end{array}$} & \multicolumn{5}{|c|}{ Left Injection } & \multicolumn{5}{|c|}{ Right Injection } \\
\hline & & $\begin{array}{l}\text { Minutes } \\
\text { after } \\
\text { Injection }\end{array}$ & Counting & Naming & $\begin{array}{l}\text { Right } \\
\text { Motor } \\
\text { Power }\end{array}$ & $\begin{array}{l}\text { Left } \\
\text { Motor } \\
\text { Power }\end{array}$ & $\begin{array}{l}\text { Minutes } \\
\text { after } \\
\text { Injection }\end{array}$ & Counting & Naming & $\begin{array}{l}\text { Right } \\
\text { Motor } \\
\text { Power }\end{array}$ & $\begin{array}{l}\text { Left } \\
\text { Motor } \\
\text { Power }\end{array}$ \\
\hline $\begin{array}{l}1 \\
\text { A.H. }\end{array}$ & 150 & $\begin{array}{l}0 \frac{1}{2} 111 \frac{1}{2} 2 \\
2 \frac{1}{2} 345\end{array}$ & $\begin{array}{lllll}0 & 0 & 0 & 0 & 0 \\
1 & 24 & 4 & 4\end{array}$ & $\begin{array}{lllll}0 & 0 & 0 & 0 & 0 \\
0 & 1 & 4 & 4\end{array}$ & $\begin{array}{lllll}0 & 0 & 0 & 0 & 0 \\
0 & 1 & 3 & 4\end{array}$ & $\begin{array}{l}44444 \\
4444\end{array}$ & 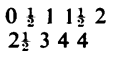 & $\begin{array}{lllll}0 & 0 & 0 & 0 & 1 \\
1 & 1 & 3 & 4\end{array}$ & $\begin{array}{lllll}0 & 0 & 0 & 0 & 0 \\
0 & 3 & 3 & 4\end{array}$ & $\begin{array}{l}44444 \\
4444\end{array}$ & $\begin{array}{lllll}0 & 0 & 0 & 0 & 0 \\
0 & 1 & 3 & 4\end{array}$ \\
\hline $\begin{array}{l}2 \\
\text { B.L. }\end{array}$ & 200 & 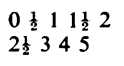 & $\begin{array}{lllll}0 & 0 & 0 & 0 & 0 \\
0 & 1 & 3 & 4\end{array}$ & $\begin{array}{lllll}0 & 0 & 0 & 0 & 0 \\
0 & 1 & 1 & 4\end{array}$ & 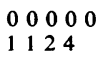 & $\begin{array}{l}44444 \\
4444\end{array}$ & $\begin{array}{l}0 \frac{1}{2} 11 \frac{1}{2} 2 \\
2 \frac{1}{2} 345\end{array}$ & $\begin{array}{l}00000 \\
1234\end{array}$ & $\begin{array}{lllll}0 & 0 & 0 & 0 & 0 \\
0 & 1 & 1 & 4\end{array}$ & $\begin{array}{l}44444 \\
4444\end{array}$ & $\begin{array}{lllll}0 & 0 & 0 & 0 & 0 \\
1 & 2 & 3 & 4\end{array}$ \\
\hline $\begin{array}{l}3 \\
\text { E.S. }\end{array}$ & 200 & $\begin{array}{l}0 \frac{1}{2} 111 \frac{1}{2} \\
2 \frac{1}{2} 34\end{array}$ & $\begin{array}{lllll}0 & 0 & 0 & 0 & 0 \\
1 & 1 & 44\end{array}$ & $\begin{array}{lllll}0 & 0 & 0 & 0 & 0 \\
0 & 1 & 3 & 4\end{array}$ & $\begin{array}{llll}0 & 0 & 0 & 000 \\
1 & 2444\end{array}$ & $\begin{array}{l}44444 \\
4444\end{array}$ & $\begin{array}{l}0 \frac{1}{2} 111 \frac{1}{2} 2 \\
2 \frac{1}{2} 345\end{array}$ & $\begin{array}{llllll}0 & 0 & 0 & 0 & 1 \\
2 & 2 & 2 & 4\end{array}$ & $\begin{array}{lllll}0 & 0 & 0 & 0 & 0 \\
0 & 2 & 3 & 4\end{array}$ & $\begin{array}{l}44444 \\
4444\end{array}$ & $\begin{array}{lllll}0 & 0 & 0 & 0 & 0 \\
1 & 1 & 1 & 4\end{array}$ \\
\hline $\begin{array}{l}4 \\
\text { E.K. }\end{array}$ & 200 & $\begin{array}{l}0 \frac{1}{2} 11 \frac{1}{\frac{1}{2}} 2 \\
2 \frac{1}{2} 345\end{array}$ & $\begin{array}{lllll}0 & 0 & 0 & 0 & 0 \\
2 & 3 & 4 & 4\end{array}$ & $\begin{array}{lllll}0 & 0 & 0 & 0 & 0 \\
1 & 2 & 3 & 4\end{array}$ & $\begin{array}{lllll}0 & 0 & 0 & 0 & 0 \\
0 & 1 & 3 & 4\end{array}$ & $\begin{array}{l}44444 \\
4444\end{array}$ & $\begin{array}{l}0 \frac{1}{2} 11 \frac{1}{2} \\
2 \frac{1}{2} 345\end{array}$ & $\begin{array}{lllll}0 & 0 & 0 & 0 & 1 \\
1 & 2 & 3 & 4\end{array}$ & $\begin{array}{lllll}0 & 0 & 0 & 0 & 0 \\
1 & 1 & 3 & 4\end{array}$ & $\begin{array}{l}44444 \\
4444\end{array}$ & $\begin{array}{lllll}0 & 0 & 0 & 0 & 0 \\
1 & 1 & 3 & 4\end{array}$ \\
\hline
\end{tabular}

Key: $0=$ Absent $\quad 1=$ Perceptible $\quad 2=$ Markedly reduced $\quad 3=$ Slightly reduced $\quad 4=$ Normal.

TABLE II

POST-OPERATIVE RESULTS OF THE INTRACAROTID AMYTAL TESTS IN FOUR PATIENTS

\begin{tabular}{|c|c|c|c|c|c|c|c|c|c|c|c|}
\hline \multirow{2}{*}{$\begin{array}{l}\text { Case } \\
\text { No. }\end{array}$} & \multirow{2}{*}{$\begin{array}{l}\text { Dose } 10 \% \\
\text { NaAmytal } \\
\text { (mg.) }\end{array}$} & \multicolumn{5}{|c|}{ Left Injection } & \multicolumn{5}{|c|}{ Right Injection } \\
\hline & & $\begin{array}{l}\text { Minutes } \\
\text { after } \\
\text { Injection }\end{array}$ & Counting & Naming & $\begin{array}{l}\text { Right } \\
\text { Motor } \\
\text { Power }\end{array}$ & $\begin{array}{l}\text { Left } \\
\text { Motor } \\
\text { Power }\end{array}$ & $\begin{array}{l}\text { Minutes } \\
\text { after } \\
\text { Injection }\end{array}$ & Counting & Naming & $\begin{array}{l}\text { Right } \\
\text { Motor } \\
\text { Power }\end{array}$ & $\begin{array}{l}\text { Left } \\
\text { Motor } \\
\text { Power }\end{array}$ \\
\hline $\begin{array}{l}1 \\
\text { A.H. }\end{array}$ & 150 & $\begin{array}{l}0 \frac{1}{2} 111 \frac{1}{2} 2 \\
2 \frac{1}{2} 345\end{array}$ & $\begin{array}{l}24444 \\
4444\end{array}$ & $\begin{array}{llll}0 & 3 & 444 \\
4 & 444\end{array}$ & $\begin{array}{lllll}0 & 0 & 0 & 0 & 0 \\
0 & 1 & 2 & 4\end{array}$ & $\begin{array}{l}44444 \\
4444\end{array}$ & $\begin{array}{l}0 \frac{1}{2} 111 \frac{1}{2} \\
2 \frac{1}{2} 345\end{array}$ & $\begin{array}{lllll}0 & 0 & 0 & 0 & 1 \\
2 & 2 & 3 & 4\end{array}$ & $\begin{array}{lllll}0 & 0 & 0 & 0 & 0 \\
1 & 3 & 4 & 4\end{array}$ & $\begin{array}{l}44444 \\
4444\end{array}$ & $\begin{array}{lllll}0 & 0 & 0 & 0 & 0 \\
0 & 1 & 3 & 3\end{array}$ \\
\hline $\begin{array}{l}2 \\
\text { B. L. }\end{array}$ & 200 & 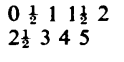 & $\begin{array}{lllll}0 & 0 & 0 & 0 & 0 \\
1 & 1 & 3 & 4\end{array}$ & $\begin{array}{lllll}0 & 0 & 0 & 0 & 0 \\
0 & 2 & 2 & 4\end{array}$ & $\begin{array}{lllll}0 & 0 & 0 & 0 & 0 \\
1 & 1 & 3 & 4\end{array}$ & $\begin{array}{l}44444 \\
4444\end{array}$ & $\begin{array}{l}0 \frac{1}{2} 11 \frac{1}{2} 2 \\
2 \frac{1}{2} 345\end{array}$ & $\begin{array}{l}14444 \\
4444\end{array}$ & $\begin{array}{llll}13444 \\
4444\end{array}$ & $\begin{array}{l}44444 \\
4444\end{array}$ & $\begin{array}{lllll}0 & 0 & 0 & 0 & 0 \\
0 & 1 & 3 & 4\end{array}$ \\
\hline $\begin{array}{l}3 \\
\text { E.S. }\end{array}$ & 200 & $\begin{array}{l}0 \frac{1}{2} 11 \frac{1}{2} 2 \\
2 \frac{1}{2} 345\end{array}$ & $\begin{array}{l}34444 \\
4444\end{array}$ & $\begin{array}{l}14444 \\
4444\end{array}$ & $\begin{array}{lllll}0 & 0 & 0 & 0 & 0 \\
0 & 3 & 4 & 4\end{array}$ & $\begin{array}{l}44444 \\
4444\end{array}$ & $\begin{array}{l}0 \frac{1}{2} 11 \frac{1}{2} 2 \\
2 \frac{1}{2} 345\end{array}$ & $\begin{array}{lllll}0 & 0 & 0 & 0 & 0 \\
2 & 2 & 3 & 4\end{array}$ & $\begin{array}{lllll}0 & 0 & 0 & 0 & 0 \\
0 & 2 & 3 & 4\end{array}$ & $\begin{array}{l}44444 \\
4444\end{array}$ & $\begin{array}{lllll}0 & 0 & 0 & 0 & 1 \\
1 & 1 & 3 & 4\end{array}$ \\
\hline $\begin{array}{l}4 \\
\text { E.K. }\end{array}$ & 200 & $\begin{array}{l}0 \frac{1}{2} 11 \frac{1}{2} \\
2 \frac{1}{2} 345\end{array}$ & $\begin{array}{llll}2 & 2 & 344 \\
4 & 444\end{array}$ & $\begin{array}{lllll}0 & 1 & 3 & 3 & 4 \\
4 & 4 & 4 & 4\end{array}$ & $\begin{array}{lllll}0 & 0 & 0 & 0 & 1 \\
1 & 3 & 4 & 4\end{array}$ & $\begin{array}{l}44444 \\
4444\end{array}$ & 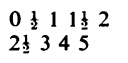 & 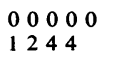 & $\begin{array}{lllll}0 & 0 & 0 & 0 & 0 \\
0 & 2 & 3 & 4\end{array}$ & $\begin{array}{l}44444 \\
4444\end{array}$ & $\begin{array}{lllll}0 & 0 & 0 & 0 & 0 \\
2 & 2 & 2 & 4\end{array}$ \\
\hline
\end{tabular}

Key: $0=$ Absent $\quad 1=$ Perceptible $\quad 2=$ Markedly reduced $\quad 3=$ Slightly reduced $\quad 4=$ Normal. 
left frontal tumour mass. On the following two days, with the patient awake, carotid amytal tests were done which showed bilateral cerebral representation of speech (Table I). Speech was represented on the left hemisphere.

Surgical exploration revealed a tumour involving the left premotor region of the frontal lobe of the brain. This seemed well circumscribed and accordingly it was resected. Histological examination showed it to be a grade III astrocytoma (Cushing-Bailey).

Post-operatively the patient had a minimal right hemiparesis but spoke normally without stammering.

Tests for cerebral representation of speech were repeated three months post-operatively and speech representation was found to be present only on the right side (Table II). The patient's speech was normal at that time and has continued to be normal to the present (18 months post-operatively).

CASE 2 B.L. (Lankenau Hospital case no. A 60528) was a man aged 27 years, who was right handed, right footed, right eared, and left eyed.

He was the second of two siblings. Delivery was normal, as was early development, but, according to the parents of the patient, acquisition of speech was much delayed so that he was not capable of using adequate sentences until the age of 5 or 6 years. The father was left handed and his brother was 'ambidextrous'. The patient's maternal grandmother was also left handed.

The patient had stammered since early childhood. The exact age and manner of onset was not recalled by the parents.

Neurologically, the patient was well until the sudden onset of a subarachnoid haemorrhage, when he was admitted to hospital and angiography done. This study revealed an aneurysm of the right anterior cerebral artery. On the following two days intracarotid amytal tests were done under local anaesthesia, and showed bilateral cerebral representation of speech (Table I).

Carotid compression was withstood without difficulty, but the patient suddenly started to deteriorate on the following day which precipitated immediate direct surgical intervention. Temporary occluding clips were placed on the right anterior cerebral artery before clipping the aneurysmal neck.

Post-operatively the patient was stuporous for three days: as his consciousness returned he had dysphasia and a left hemiparesis. Within one week the dysphasia cleared and the patient was speaking normally without stammering.

Repeat intracarotid amytal testing three months postoperatively revealed only left-sided speech representation (Table II). The patient's speech has continued to be normal up to the present time (15 months postoperatively).

CASE 3 E.S. (Lankenau Hospital case no. B 69561), a woman, aged 36 years, was left handed, right eyed, right eared, and left footed.

Delivery was normal, and she was an only child. Neither parent was left handed but the father was classified as being 'ambidextrous' and both maternal and paternal grandfathers were left handed. Early develop- ment was normal but the parents felt that she was a 'clumsy' child during early grammar school years. She $Z$ had always had much difficulty with spelling, reading, and writing.

The patient had stammered since early life, and if $\stackrel{\infty}{\subseteq}$

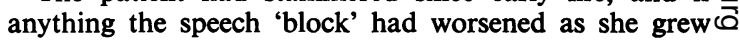
older and became involved in taxing life situations.

Neurologically the patient was well before a sudden subarachnoid haemorrhage, when she was admitted to $\stackrel{\circ}{\overrightarrow{0}}$. hospital and angiography done. This revealed an anterior $\stackrel{0}{\rightleftharpoons}$ communicating artery aneurysm which filled from the? left side. Carotid compression was not tolerated on either $\overrightarrow{\vec{F}}$ side. Before a second arteriogram, intracarotid amytal $\stackrel{\rho}{?}$ tests were done and the patient was shown to have bilateral representation of speech (Table I).

Direct operative intervention was decided upon and in $\overline{\frac{\omega}{m}}$ the course of the operation it was necessary to clip the $\mathbb{\varnothing}$ left anterior cerebral artery since the aneurysm seemed to arise almost at the junction of the anterior communicating $\infty$ with the left anterior cerebral artery.

Post-operatively the patient was comatose for about a week, stuporous for another week, and thereafter was $\vec{\omega}$ dysphasic and had a right hemiparesis. The dysphasia $\stackrel{?}{S}$ cleared in three to four days and the patient began to speak normally, i.e., without stammering.

The hemiparesis remained unchanged at the time of her discharge from the hospital and she required subsequen $\omega$ treatment in a rehabilitation centre for two months.

Three months post-operatively the intracarotid amyti 10 test was repeated and only right-sided speech represent $\overrightarrow{\mathrm{B}}$ 응 tion was shown (Table II). The patient's speech ha्gs continued without stammering (now 27 months postoperatively). ${ }^{1}$

CASE 4 E.K. (Lankenau Hospital case no. C 18502) man, aged 50 years, was left handed, left eyed, righ eared, and right footed.

Delivery was normal, and he was the second of six children. The father was left handed and the mother ambidextrous. Early development was normal, and he had no apparent difficulty with reading or writing and did well at school. Of the other siblings, four were classi- $\stackrel{\mathbb{Q}}{\triangle}$ fied as being right handed. (These subjects were not $\underset{\vec{F}}{\overrightarrow{2}}$ personally tested for handedness or dominance but it is known that some of their actions were done with the left hand.) Two were classified as left handed.

The patient's prior medical history was pertinent in that he became obese, had gall bladder symptoms, and had been under a physician's care for arterial hypertension for the year preceding admission.

The patient began to stammer at about 6 years of age, 3 and the stammering had remained about the same in intensity since its onset.

Neurologically, the patient was well until the sudden onset of a subarachnoid haemorrhage. Preliminary을 arteriography revealed an aneurysm of the left middle $>$ cerebral artery. The arterial punctures were repeated on the following two days under local anaesthesia and intracarotid amytal tests were done, which showed bilateralos cerebral representation of speech (Table 1 ).

Direct operative intervention was decided upon and the

${ }^{1}$ This patient recently died in an automobile accident.

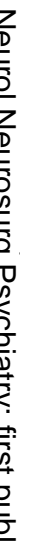


aneurysmal neck was clipped. The patient did poorly post-operatively, remaining stuporous for 10 days. There was a profound hemiplegia. Repeat angiography revealed occlusion of the left middle cerebral artery. Shortly afterwards he became better and started to speak after a few days of dysphasia, when his speech was normal.

Re-evaluation of the patient three months postoperatively with the intracarotid amytal test revealed only right-sided speech representation (Table II). Speech has continued to be normal up to the present time (three years post-operatively).

\section{DISCUSSION}

Quite apart from the effect obtained as the result of treatment directed to the various pathological entities existing in these four patients, these results confirm, in the first place, particularly on the evidence presented in Table $I$, that there was a substantial bilateral representation of the speech mechanism in these four patients. This supports the view previously put forward, but unproved, by Travis (1900), that bilateral cortical representation is a factor in stammering.

The results on stammering of a one-sided operation for unrelated lesions in these four patients were quite startling and can only be explained by the view that stammering is associated with an interference by one hemisphere with the speech performance of the other. This is a new conception which seems to emerge clearly from a study of these patients.

Perhaps the most surprising of all, however, is the finding that the intracarotid amytal test on the side of the lesion no longer interferes with speech after the operation as it did before. This indicates a transfer of influence to one hemisphere only, which is not only a new finding but suggests possible plasticity and changes in the inter-hemispheric relationship which are quite remarkable despite their occurrence in a very restricted type of individual.

SUMMARY

Four stammerers who required operation on one cerebral hemisphere have been studied. They all, before operation, developed aphasia during intracarotid amytal testing from both hemispheres. After operation on one cerebral hemisphere stammering ceased.

Intracarotid amytal tests after operation and after stammering had ceased showed that aphasia was now only produced from the side of the brain that had not been operated on. These findings throw new light on inter-hemispheric organization with special reference to speech.

I would like to express my profound gratitude to Professor W. R. Russell for his patient understanding and advice in the preparation of this paper.

\section{REFERENCES}

Branch, C., Milner, B., and Rasmussen, T. (1964). Intracarotid sodium amytal for the lateralization of cerebral speech dominance. Observations in 123 patients. J. Neurosurg., 21, 399-405.

Bryngelson, B. (1932). Sidendnes as an etiological factor in stuttering. Proc. Amer. Speech Correction Ass., 2, 91-102.

Nielson, J. M. (1946). Agnosia, Apraxia, Aphasia, 2nd ed. Hoeber, New York.

Penfield, W., and Roberts, L. (1959). Speech and Brain-mechanisms. Princeton University Press, Princeton, N.J.

Travis, L. E. (1931). In Speech Pathology. Appleton, New York.

Wada, J., and Rasmussen, T. (1960). Intracarotid injection of sodium amytal for the lateralization of cerebral speech dominance. Experimental and clinical observations. J. Neurosurg., 17, 266-282. 